\title{
Engineering principles for the design of a personnel transportation system
}

\author{
by R.C.W. Webber-Youngman* and G.M.J. van Heerden ${ }^{\dagger}$
}

\section{Synopsis}

This article describes the re-engineering principles applied in the design of a personnel transportation system for the Bafokeng Rasimone Platinum Mine in the Rustenburg area of South Africa. It incorporates conveyor belt travelling, chairlift operation, and also includes consideration of proposed changes/modifications to the existing conveyor belt infrastructure.

The purpose of the project was to identify, through a process of evaluation, the appropriate option and/or combination of transportation options that would be safe in terms of personnel transportation as well as cost-effective. Alternative measures for transporting personnel (not using belt riding) would have a significant positive spin-off, increasing the availability of the belt and thereby increasing production. This paper explores the feasibility of interventions that would improve safety through eliminating risk associated with personnel transportation as well as contributing towards improving the mine's position on the cost curve.

The design in consideration at the Bafokeng Rasimone Platinum Mine consists of two shaft systems, namely the North Shaft and South Shaft, each comprising twin decline shafts. One of the decline shafts is equipped with a conveyor belt for rock and personnel transportation, and the other with a winder for trackbound material transport. The conveyor belt has been used for personnel transportation since the commissioning of the shafts. The conveyor belt is equipped with platforms for personnel getting off and on the belt and a number of safety devices designed to ensure safety while travelling on the belt. Intensive training in the practical aspects of belt riding is given to every person, and unsupervised riding on the belt is permitted only once belt riding competence is demonstrated. Despite this, the safety results were poor, with 106 injuries between 2006 and May 2013. Fortunately, no fatalities were reported during this period.

An investigation of alternative means for personnel transportation or engineered solutions to the current conveyor belt infrastructure in the safest, most effective, and most economical way was therefore needed. There was a major risk of safety-related stoppages being imposed following another belt accident/incident. This would prevent the mine from transporting personnel underground by belt and result in major production losses. From the commissioning of the Phase 2 shaft deepening project on both shafts, dedicated chairlifts have been used for personnel transportation as opposed to the conveyor belt installed in the Phase 1 area. The chairlifts have been in operation since 2004 and no chairlift-related incidents have been recorded thus far. According to safety statistics, it is clear that the chairlift is the safer method for the transportation of people in the shaft.

To fulfil the objectives/scope of this study, it was recommended that both primary (new chairlift decline with infrastructure) and secondary options (modifications to the current conveyor belt infrastructure) be considered for implementation on both the North Shaft and South Shaft to reduce or eliminate accidents/incidents as a result of belt transportation. The associated capital expenditure would be approximately R200 million. Considering the future impact on the business as a whole, this would definitely be capital well spent.

Keywords personnel transportation, conveyor belt, chairlift, re-engineering, evaluation.

\section{Introduction}

In any mining operation, labour is one of the most valuable resources. In order to ensure that the personnel get to the workplace safely and in time, it is important to plan and design a transportation system that also meets the required production output of the mine. The extent of the system will be determined by a number of factors. These are the mining layout, the size of the orebody, the mining method, and the number of people to be transported at any given time. This also relates to the travelling time and the actual time spent in the workplace.

During the last decade and a half, numerous declines were developed to either access deeper reserves that were inaccessible from the existing vertical infrastructure, or new declines from surface to access suboutcrop material that was left in the past. With the change in the economic environment and the increase in demand, it became imperative to mine the available resources.

Several of these declines were planned and designed without considering the future impact of not installing a proper, effective and safe personnel transportation system. Therefore the wrong decisions and designs were adopted upfront. The Khuseleka 1 Shaft of Anglo American Platinum (AAP) is an example. When the decline was developed (September 1991), $1.1 \mathrm{~km}$ away from the current vertical shaft infrastructure, the decision was that the employees would either walk the horizontal distance, or be transported by means of trackbound personnel carriages. The latter option was found not to be viable and was replaced by a horizontal chairlift in July 2013. 


\section{Engineering principles for the design of a personnel transportation system}

In some cases the existing personnel transportation system had to be altered or redesigned as it was jeopardizing the operation of the mine due to the poor safety and health statistics and risks associated with the system. The Bafokeng Rasimone Platinum Mine (BRPM), as discussed in this paper, is an example. In some instances, personnel transportation was not even taken into account. With the deepening of the operations, the travelling distances increase and actual face time is reduced, adversely affecting the productivity of employees. Alternatives have been investigated to try to minimize the damage already caused. At AAP's Bathopele Mine, for example, when the two declines (East and Central shafts) were developed in 1999, no provision was made for personnel transportation. This was not a concern during the early stages of the operation and employees easily walked in and out the shaft. When the vertical distances to the workplaces increased beyond $150 \mathrm{~m}$, the mine had to provide alternative means of transport. Personnel carriers (PC) were purchased in 2006 for each section with additional for spare during maintenance cycles. Light diesel vehicles (LDVs) were also provided for supervision. The mechanized equipment was maintained by the original equipment manufacturers (OEMs).

Several design principles have to be considered when a personnel transportation system for a mine is reviewed, especially if a system is already in place. The design parameters applicable in such a case have to concurrently consider several other factors that will have a short-, medium-, and long-term impact on production. Other critical parameters such as safety, health, and environmental impacts also need to be considered. This needs to be done in the most economical way possible. The design principles considered in the re-engineering of transportation systems was done through a case study at BRPM.

\section{Bafokeng Rasimone platinum mine (BRPM)}

BRPM was established to exploit platinum group metals (PGMs) in the Merensky Reef (MR) and Upper Group 2 (UG2) reefs on the Boschkoppie, Frischgewaagd, and Styldrift farms in the Rustenburg area. BRPM is close to Boshoek in the North West Province of South Africa (RSA). (BRPM MES, 2008).

\section{Mine layout and existing personnel transportation system}

BRPM consists of two shaft systems, namely the North Shaft and South Shaft, each comprising twin decline shafts. One of the decline shafts is equipped with a conveyor belt for rock and personnel transportation and the other with a winder for trackbound material transport.

From the date of commissioning the conveyor belt was used for personnel transport. The conveyor belt is equipped with platforms for getting off and on the belt and a number of safety devices, designed to ensure the safety of personnel travelling on the belt. Despite all the approved engineering solutions, the mine continued to experience poor safety results. Mine management decided that from the commissioning of the Phase 2 shaft deepening project on both shafts, dedicated chairlifts for personnel transportation would be installed as opposed to the man-riding conveyor belt installed in the Phase 1 area. At North Shaft the Phase 1 area extends up to and including level 5, and at South Shaft up to and including level 6.

It was important to identify specific challenges related to the belt transportation system so as to be able to obtain feasible solutions in a new design, such as the mine extraction strategy (MES), safety statistics related to conveyor belt riding, and all challenges experienced with conveyor belt riding.

\section{Mine extraction strategy (MES)}

When considering the MES, it is evident that if a solution to the current method of personnel transportation is not found, the risk of injuries/incidents on the belt could persist for many years to come. BRPM was mining only the MR on the farm Boschkoppie from North Shaft and South Shaft at the time of the study. Mining the UG2 will play an important role in achieving the long-term plan (LTP) production profiles as prescribed in the MES. The LTP production profiles of the MES illustrate the duration that the proposed chairlifts will be in operation, as shown in Figure 1. North Shaft will be in operation beyond 2060 and South Shaft up to 2050. At the time of the study the focus was only the Boschkoppie area, where the current two shafts were in operation (BRPM MES, 2008).

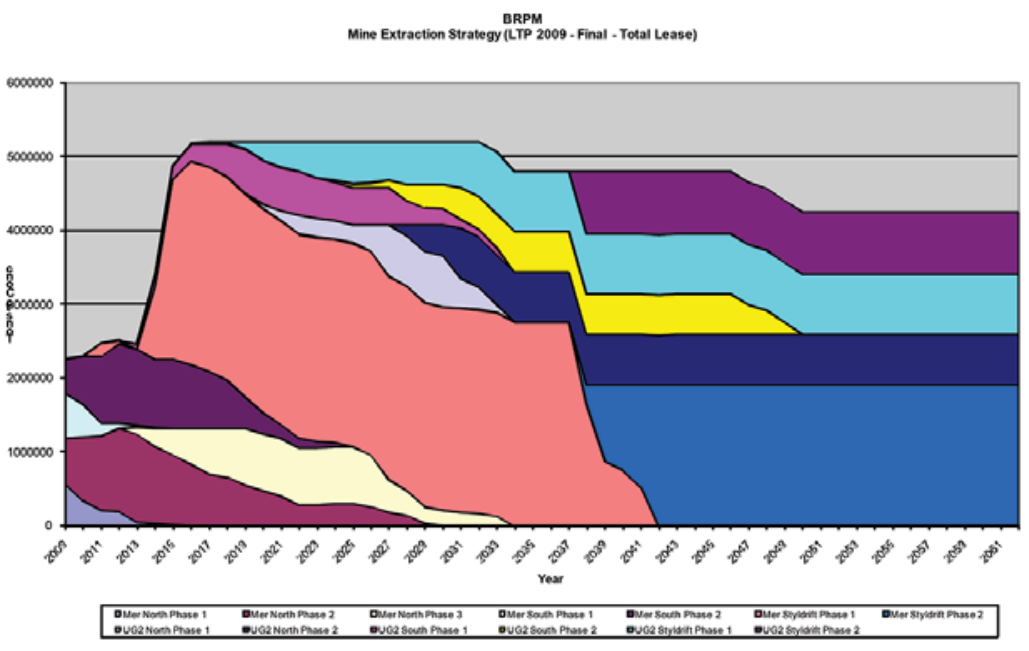

Figure 1-LTP profile for the entire BRPM lease area (both MR and UG2 reefs) (Van Heerden, 2008) 


\section{Engineering principles for the design of a personnel transportation system}

\section{Safety-related incidents associated with conveyor belt riding}

Poor safety was experienced with conveyor belt transportation of personnel, with 106 injuries reported from 2006 to May 2013. Figure 2 illustrates the classes of injuries and the number of injuries per class. During this period, 70\% of the injuries were medical treatment cases (MTCs) with no shift/day lost, 20\% were lost time injuries (LTIs) with less than 14 days lost, and 10\% were serious injuries (SIs) resulting in more than 14 days lost. Of these 106 injuries, 98 $(92.5 \%)$ were incurred while going down and coming up from underground, with the remaining $8(7.5 \%)$ taking place during training. The training includes both practical training on the surface conveyor belt facility at North Shaft as well as applying the knowledge acquired on the actual underground conveyor belt. Since BRPM became operational in 1999, only one fatal accident has resulted from belt riding. It was assumed that a worker fell asleep while travelling on the man-riding conveyor belt from 5 level to surface. The deceased passed through the "wake-up conveyors and chains', underneath the safety devices, and past the cap lamp transponder receiver. He was subsequently tipped into the belt transfer chute onto the overland conveyor. The deceased was not wearing a cap lamp and as a result the final safety device (the cap lamp transponder receiver) did not stop the belt (BRPM Safety Department, 2013).

\section{Challenges experienced with conveyor belt riding}

Seventy-one of the injuries that were reported happened when personnel travelled down the mine $(72.5 \%)$. This is significant, as the average person travelling down the mine will get on and off the belt only once on the downward trip (at this time no rock is being transported on the belt). The same person may repeat this process up to five times on the way out of the mine due to the configuration of the level orepasses and chute infrastructure. This means that a person will have to get off the belt several times (rock is now being transported out of the mine and personnel have to get off the belt for rock to be tipped onto the belt at different levels). The personnel then walk around the chute and get back onto the belt. This is at the end of the shift, with personnel struggling with fatigue and consequently the risk of making mistakes. Despite this, most accidents happen on the way down the mine.

Belt riding injuries January 2006 to 2013 (27 May 2013)

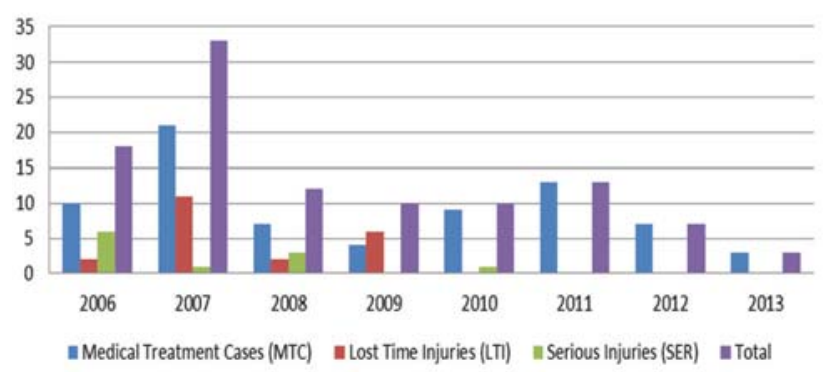

Figure 2-Classes and number of injuries per class (BRPM and Van Heerden, 2013)

\section{Getting off the belt (going down the mine)}

of the 71 injuries recorded, 55 (77\%) occurred while getting off the belt going down the mine. Sixty-five percent of the injuries related to the knees (27\%), ankles (27\%), feet (4\%), and abdomen (7\%). A breakdown of the injuries recorded is shown in Figure 3. This is definitely the most physically taxing of the tasks carried out during conveyor riding, due to the fact that the legs are forced to absorb the force imparted by the belt moving at $2.5 \mathrm{~m} / \mathrm{s}$ combined with the natural acceleration due to gravity which, at an inclination of $-9^{\circ}$ amounts to $1.7 \mathrm{~m} / \mathrm{s}^{2}$. This combination requires a person to decelerate at the equivalent of $2.95 \mathrm{~m} / \mathrm{s}^{2}$ in order to stop in the required distance.

\section{Getting off the belt (going out the mine)}

of the 27 injuries recorded, 15 (56\%) occurred while getting off the belt going out the mine. An analysis indicated different types of injuries compared with those suffered when getting off the belt going down the mine. The injuries were classified as follows: head (19\%) and facial (including jaw, nose, eye, and ear) $22 \%$, which equated to 11 of the 27 (41\%), followed by fingers (15\%), hands $(7 \%)$, and elbow (7\%), 8 of the 27 (30\%); and the knees, ankles. and feet, 3 of the $27(12 \%)$. From this it was obvious that injuries occur when people fall over while getting off the belt. A breakdown of these injuries is presented in Figure 4. Getting off the belt is physically very taxing as the normally high friction coefficient between a rubber boot and rubber conveyor is

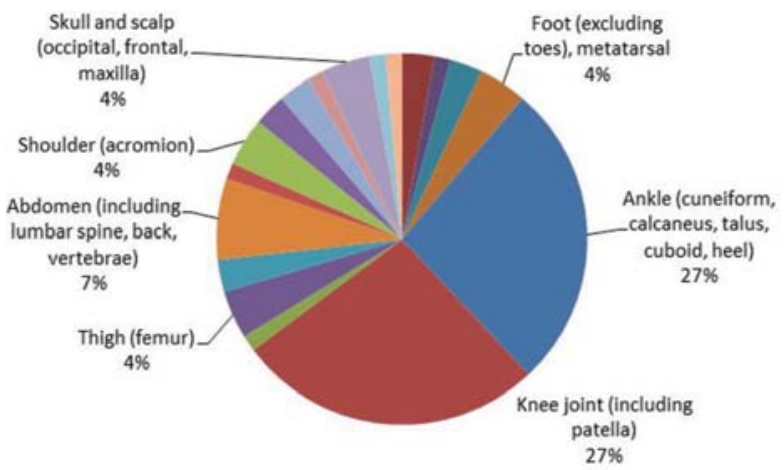

Figure 3-Breakdown of injuries - getting off the belt (going down the mine) (BRPM and Van Heerden, 2013)

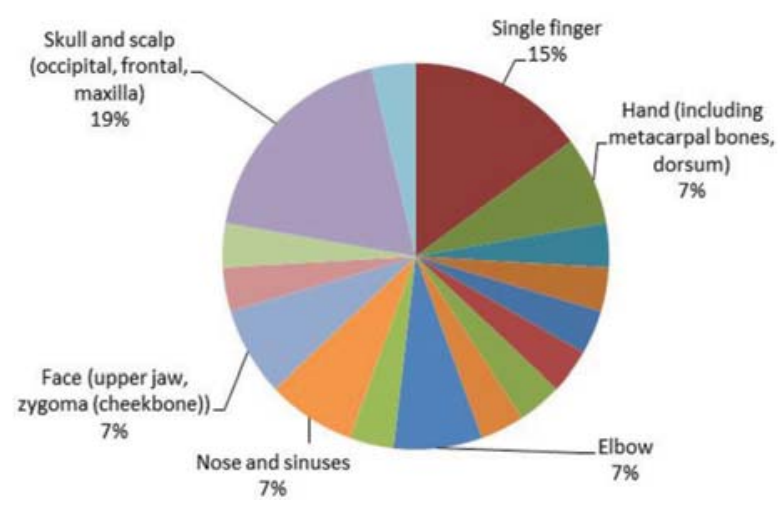

Figure 4-Breakdown of injuries - getting off the belt (going out the mine) (BRPM and Van Heerden, 2013) 


\section{Engineering principles for the design of a personnel transportation system}

reduced by the presence of small rock particles, making it very difficult to gain the necessary purchase when launching off the belt. Getting on the belt is risky for the same reasons. The presence of rock on the conveyor complicates getting on and off the belt. When comparing the number of injuries recorded going down the mine with going out the mine it is evident that the latter involves less risk due to natural deceleration imparted by gravity, which has the effect of stopping one almost as one lands on the platform, requiring almost no effort at all.

\section{Conveyor belt training}

There is a dedicated conveyor belt training facility at North Shaft. Once personnel have completed their medical examination and are proven fit for underground work (including induction and work-related training modules), belt training is done. Intensive training with regard all the practical aspects of belt riding is given to all personnel. Unsupervised riding on the belt is allowed only once competence is demonstrated. Competency is demonstrated both on the surface training belt and then on the actual underground belt at North Shaft.

In the event of belt stoppages due to accidents and/or maintenance no further travelling on the belt will be possible. This clearly indicates the vulnerability of the system in terms of personnel transportation, for which the conveyor belt is the only way of going down or getting out from underground. This will have a major production impact. Furthermore, the Mine Health and Safety Act (MHSA) also gives specific guidance with regard to the allowable vertical distance for unaided travelling.

Accordingly, and in line with BRPM's safety strategy, investigations were undertaken to identify safer engineering solutions to the current transportation system and identify alternative means of personnel transportation that could be implemented to reduce or eliminate incidents or injuries related to belt riding.

\section{Critical items to be considered in the re-engineering investigation}

It was necessary to identify through an evaluation process the appropriate option or combination of applicable transport systems that would be suitable for BRPM, taking into consideration safety as well as cost-effectiveness. Incorporation of suitable alternative personnel transportation systems could result in a significant increase in production due to an increase in belt availability. Some of the key parameters considered in the evaluation process were as follows:

> The safety and health risk involved in continued usage of the conveyor belt infrastructure for personnel transportation

- The effect of belt safety stoppages on production

- Availability of alternative personnel transportation systems

- The process of option selection and decision analysis, where no option is discarded until proven to be ineffective, unsafe, impracticable, or uneconomical

- Detail design and scheduling, costing, and effect on life of mine profile

> Involvement of relevant responsible departments such as engineering, rock engineering, geology, and ventilation that could play an important role during the selection and analysis of the various options

- Evaluating the current personnel transportation system in terms of optimizing production and reducing the risk of incidents / injuries

> Possible modifications to the current conveyor belt infrastructure while new systems are being implemented

> Benchmarking of proposed design criteria against actual achievements in terms of production, construction, and costs.

\section{Process of option elimination}

Initially, 17 different options were identified during process one (P1), which was a brainstorming workshop involving all stakeholders. Table I shows the different options considered and that were found to be most applicable for the two shafts. During this stage of the process no option was deemed impossible or discarded based on:

> Capital expenditure (CAPEX)

- Practicality in terms of implementation

> Timing in terms of the life of mine (LOM) profile, in line with the MES

> Accessibility from current infrastructure or through consideration of local communities surrounding the mine.

> Safety or impact on surface infrastructure (communities).

Following a process of elimination (P2), the decision was taken to further investigate six options at North Shaft and nine at South Shaft. Only three options were selected at North Shaft for further consideration (P3), one being a totally new chairlift decline with infrastructure (primary option) and the other two modifications to the current conveyor belt and belt infrastructure (secondary options).

Five options were selected at South Shaft during P3 for further consideration, three of which involved totally new declines with infrastructure (primary options) and two being modifications to the current conveyor belt and belt infrastructure (secondary options). At the end of P3, only one primary and one secondary option were selected. These were the new chairlift decline with new infrastructure, and safer platforms for getting on and off the conveyor belt. The secondary options were proven feasible for each of the shafts (application in the North Shaft is discussed in detail later in this article). Table II details the options selected during P3 as well as the final options selected for North Shaft.

For each of the options, the following were considered:

> Detailed design, scheduling, supply, delivery, construction, and commissioning of a chairlift system from surface to level 5 at North Shaft and level 6 at South Shaft

> Strengths, weaknesses, opportunities, and threats (SWOT) analysis for each of the options

> Project duration from start of development to commissioning, and the fit with the LOM profile

> Utilizing the current MR infrastructure

- Starting development of the chairlift decline from different positions simultaneously (various attack points) 


\section{Engineering principles for the design of a personnel transportation system}

\begin{tabular}{|c|c|c|c|c|}
\hline \multirow{2}{*}{\multicolumn{5}{|c|}{$\begin{array}{l}\text { Table I } \\
\text { Different options identified during process one (P1) }\end{array}$}} \\
\hline & & & & \\
\hline Option & \multirow{2}{*}{$\begin{array}{l}\text { Description } \\
\text { Chairlift in current belt decline }\end{array}$} & \multirow{2}{*}{ North \# } & \multirow{2}{*}{$\begin{array}{c}\text { South \# } \\
\times\end{array}$} & Comment \\
\hline 1 & & & & Sliping required - damage to belt \\
\hline $2 a$ & Chairlift in zero raise - decline from surface & $x$ & $\sqrt{ }$ & $\begin{array}{l}\text { N\# zero raise line not straight and continuous. } \\
\text { S\# applicable for further investigation }\end{array}$ \\
\hline $2 \mathrm{~b}$ & Chairlift in zero raise - vertical shaft to surface & $x$ & $x$ & Surface infrastructure / communities \\
\hline 3 & New chairlift decline - new infrastructure & $\sqrt{ }$ & $\sqrt{ }$ & High CAPEX \\
\hline 4 & Vertical shaft from surface to 3 level & $\mathbf{x}$ & 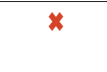 & $\begin{array}{l}\text { Still need transport / travelling through workings to } \\
\text { upper levels }\end{array}$ \\
\hline 5 & Multiple chairlifts in ventilation bypass areas & $x$ & * & $\begin{array}{l}\text { Extensive infrastructure required with additional } \\
\text { development }\end{array}$ \\
\hline 6 & Slower personnel - riding speed & $\sqrt{ }$ & $\sqrt{ }$ & Applicable for further investigation \\
\hline 7 & Single chairlift at South 40 position for both shafts & $\times$ & $*$ & $\begin{array}{l}\text { Logistical and infrastructure constraints (single access } \\
\text { between shafts) }\end{array}$ \\
\hline 8 & $\begin{array}{l}\text { One-way chairlift down belt decline, up zero raise } \\
\text { (continuous loop) }\end{array}$ & $\sqrt{ }$ & $\sqrt{ }$ & $\begin{array}{l}\text { Need connection to surface, engineering challenges } \\
\text { when considering infrastructure installation in loop configuration }\end{array}$ \\
\hline 9 & Licence material winder for personnel transportation & $x$ & $x$ & Impact on already tight material supply schedule \\
\hline 10 & Safer platforms for getting off the belt & $\sqrt{ }$ & $\sqrt{ }$ & Applicable for further investigation \\
\hline 11 & 1st leg chairlift in belt decline then in zero raise & x & * & $\begin{array}{l}\text { Sliping required - damage to conveyor belt and belt } \\
\text { infrastructure }\end{array}$ \\
\hline $12 a$ & Chairlift in zero raise - incline under opencast & $\mathbf{x}$ & $\sqrt{ }$ & $\begin{array}{l}\text { N\# zero raise line not straight and continuous. S\# applicable } \\
\text { for further investigation }\end{array}$ \\
\hline $12 \mathrm{~b}$ & Chairlift in zero raise - portal in opencast highwall & $x$ & $\sqrt{ }$ & $\begin{array}{l}\text { N\# zero raise line not straight and continuous. } \\
\text { S\# applicable for further investigation }\end{array}$ \\
\hline 13 & Vertical shaft from surface to 5 level at N\# and 6 level at S\# & $x$ & $x$ & Still need transport / travelling through workings to upper levels \\
\hline 14 & Monorail system & $\sqrt{ }$ & $\sqrt{ }$ & Applicable for further investigation \\
\hline 15 & New decline on UG2 horizon & 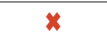 & * & Much higher CAPEX compared to MR horizon options \\
\hline 16 & Additional belt riding conveyor in belt decline & $\sqrt{ }$ & $\sqrt{ }$ & Applicable for further investigation \\
\hline 17 & Hector pipe & $\boldsymbol{x}$ & $\mathbf{x}$ & No personnel transport to surface, only down the mine \\
\hline
\end{tabular}

Table II

Different options identified during process three (P3) - North Shaft

\begin{tabular}{|l|c|c|c|}
\hline Option & Description & North \# & Comment \\
\hline 3 & New chairlift decline - new infrastructure & $\sqrt{ }$ & High CAPEX. Applicable for further investigation \\
\hline 6 & Slower personnel-riding speed & $\sqrt{ }$ & VSD installed. Effects of VSD to be investigated \\
\hline 10 & Safer platforms for getting off the belt & $\sqrt{ }$ & Applicable for further investigationa \\
\hline
\end{tabular}

Access to both MR (current operation) and UG2 (future operation)

> Increased future ventilation flow to the UG2 horizon.

Other factors considered during the selection process:

$>$ CADSMine design and scheduling of the primary options for both shafts

> CAPEX estimation (capital development, civil engineering works, piping, electrical, mechanical, structural, instrumentation, 10\% contingency, and chairlift installation)

> Financial evaluation and trade-off against major risks (i.e. complete belt safety stoppages resulting in total production stoppage)

> Risk analysis (from an engineering, rock engineering, geology, planning, and ventilation perspective)
- Timing in terms of the LTP and layout designs

- Access control on surface (surface transportation from lamp room to chairlift)

> Access to different levels and safety on levels when moving from one chairlift leg to another.

Other critical issues:

> Development end sizes of chairlift decline

> Lengths of different legs required and the drive stations required accommodating the layout

> Alternative travelling route for personnel when chairlift is not running due to maintenance or breakdown

- Access control at landings on different levels

> Comparison between different development and sinking methodologies - conventional, mechanized, raisebore, etc. 


\section{Engineering principles for the design of a personnel transportation system}

\section{Literature study}

BRPM currently uses conveyor belts for transporting personnel down and out of North and South Shafts, with the same conveyor belt being used for personnel and broken rock (reef and waste). The proposal was to either install chairlifts dedicated to personnel transport, or investigate alternative options for personnel transportation or modifications to the current conveyor belt and infrastructure and use the conveyors entirely for broken rock transportation. The updated and improved system will help to reduce safetyrelated injuries/incidents and provide capacity for increased tonnage output. Table III summarizes the literature study on personnel transportation systems for hard-rock decline shaft systems employed in the past, which that was conducted prior to the study of potential solutions for BRPM.

\section{Analysis and evaluation of results}

Detailed analyses and comparisons were done for both North Shaft and South Shaft. As the processes and outcomes of the two studies were similar, only the North Shaft study is discussed in this article. The results below summarize the investigations and provide a good overview of aspects considered in terms of the final re-engineering design decision for both systems investigated.

\section{North Shaft results}

Originally, three options were selected at North Shaft during $\mathrm{P3}$, one of which being a totally new chairlift decline with infrastructure (primary option) and two being modifications to the current conveyor belt and belt infrastructure (secondary options). Eventually only one primary and one secondary option were found feasible for North Shaft. These are summarized below.

\section{Primary option - new chairlift decline and infrastructure}

\section{Surface access and positioning}

A portal is to be created within the shaft area. This would be the most logical approach as the entire infrastructure to support this is in place and there are no additional issues, either internal (surface infrastructure) or external (surrounding communities, either formal or informal settlements) involved.

The best position for the decline would be between the UG2 and MR horizons, as this would be in competent ground and provide easy access to both the existing MR haulages and future UG2 workings. The middling between the two horizons at North Shaft is approximately $70 \mathrm{~m}$, which provides adequate space to develop the decline without impacting on the workings. The chairlift installation will begin at the exit from the existing lamp room with the first leg running to level 1. From there the decline will proceed directly to level 5 (Figure 5). Landings will be provided at each level for access to the workings (current MR and future UG2).

The outcomes of the SWOT analysis can be summarized as follows:

\section{> Strengths}

- Access to underground workings from surface

- Gives access to both MR and UG2 reef horizons
- New development can be secured for LOM (50 years) - more stable ground conditions

- Straight line - less wear and tear on moving parts

- Six attack points for quicker development.

> Opportunities

- Haulages to UG2 already in place

- Two or three legs to prevent total stoppages for maintenance or breakdown

- Additional ventilation to UG2.

The weaknesses and threats are those commonly associated with chairlift installations:

> Weaknesses

- Cost - CAPEX and maintenance

- Maintenance time - if only one leg (between levels 2 and 5)

- Breakdown time - walking the only alternative to get to surface or workplaces - shift down late and blast late

- Material cannot be taken down on chairlift.

$>$ Threats

- Long travelling distance in event of failure/stoppage (including safety stoppages)

- Maintenance time

- Workforce become negative if not running for a couple of shifts/days.

\section{Geology and rock engineering}

There are some geological features that could impact on the sinking of the chairlift decline. The major structures that could be a concern are the weathered zone (to a vertical depth of $30 \mathrm{~m}$ ), the water-bearing shear within the initial $10 \mathrm{~m}$ of sinking, a fault intersection with a $4.7 \mathrm{~m}$ throw at a dip of $80^{\circ}$, the Randal and Strike dykes, and the North Shaft UG2 fault. The decline system and some footwall development have mined successfully through these features. Specific rock engineering support recommendations need to be adhered to so as to ensure successful mining through these features. Reduced mining rates are planned when features are encountered, as benchmarked from historical information.

Jointing could also be expected. At North Shaft there are four major and two minor joint sets, which provide a clear understanding of the expected ground conditions in the vicinity of the proposed chairlift decline. Mitigating the risk is similar to mining through the geological features mentioned above.

Some additional concerns include the proximity of the two portal highwalls (proposed new portal and existing portal), the large excavations in a faulted block of ground between changes over from leg one to leg two where drive units will be installed, and the possible sterilization of some UG2 reserves due to the placement of the chairlift decline. Specific rock engineering guidance and recommendations need to be adhered too to ensure the mitigation of risk.

\section{Ventilation}

There should be no holing through to the reef planes or UG2 excavations, which could result in short-circuiting of fresh air. The ventilation controls in haulages should also be correctly placed to eliminate short-circuiting of fresh air into 


\title{
Engineering principles for the design of a personnel transportation system
}

\author{
Table III

\section{Literature study summary}

\begin{tabular}{|c|c|c|c|}
\hline Type of conveyance & Description & Significance & Applicability \\
\hline Walking & $\begin{array}{l}\text { The risks of walking are slip and fall } \\
\text { incidents/ injuries and unauthorized } \\
\text { riding of unapproved conveyances or cars } \\
\text { (Frankland, 1984). } 150 \mathrm{~m} \text { is the allowable } \\
\text { vertical distance for unaided travelling } \\
\text { (MHSA, 1996). }\end{array}$ & $\begin{array}{l}\text { In the case of BRPM, due to the configuration of the shafts } \\
\text { and the specific requirements, walking is not the } \\
\text { preferred option. }\end{array}$ & $\begin{array}{l}\text { Not applicable for } \\
\text { further investigation }\end{array}$ \\
\hline $\begin{array}{l}\text { Underground } \\
\text { conveyor belt } \\
\text { personnel } \\
\text { transportation }\end{array}$ & $\begin{array}{l}\text { The concept was originated as an optimized } \\
\text { option for both rock and personnel } \\
\text { transportation. Instead of having two } \\
\text { separate systems as well as two separate } \\
\text { excavations, the plan was combined to } \\
\text { manage both the requirements of ore and } \\
\text { waste transportation from underground as } \\
\text { well as personnel transportation to and from } \\
\text { the different levels in operation. This } \\
\text { application resulted in huge savings in } \\
\text { capital expenditure. Training and competency } \\
\text { levels of employees are very important as } \\
\text { the risks associated with belt transportation } \\
\text { are very high (BRPM and Target } \\
\text { Gold Mine, 2008-2013). }\end{array}$ & $\begin{array}{l}\text { The risk of continuous usage of the conveyor belt } \\
\text { infrastructure for personnel transportation with regards the } \\
\text { safety and health of employees. BRPM recorded a much } \\
\text { worse safety record ( } 106 \text { injuries between } 2006 \text { and May } \\
\text { May 2013) compared to Target Gold Mine ( } 6 \text { injuries } \\
\text { between } 2011 \text { and 2012). The nature of the injuries } \\
\text { recorded at BRPM was more serious compared to Target. } \\
\text { The effect on production associated with belt safety } \\
\text { stoppages. Belt riding is used as the only mode of transport. } \\
\text { lt is a condition of employment that employees use belt } \\
\text { riding as a form of transportation. Both personnel and broken } \\
\text { rock are transported via the conveyor belt. Both BRPM and } \\
\text { Target were forced to investigate alternative means of } \\
\text { personnel transportation. At BRPM it was purely due to } \\
\text { safety reasons compared to Target where they had to deal } \\
\text { with disputes from organized labour (BRPM, 2008 - 2013), } \\
\text { (Harmony Gold Mining Co Ltd v NUM and Others, 2012). }\end{array}$ & $\begin{array}{l}\text { Not applicable for } \\
\text { investigation: This } \\
\text { mode of transport was } \\
\text { not considered as an } \\
\text { option on its own, } \\
\text { however it was } \\
\text { included during the } \\
\text { consideration of } \\
\text { proposed changes / } \\
\text { modifcations to } \\
\text { existing conveyor belt } \\
\text { infrastructure }\end{array}$ \\
\hline $\begin{array}{l}\text { Chairlift personnel } \\
\text { transportation }\end{array}$ & $\begin{array}{l}\text { Chairlift installation has been widely, } \\
\text { successfully applied in underground mines } \\
\text { as a mode of transport. (Brophy, 1984). } \\
\text { The angle of installation varies from } \\
\text { horizontal to a maximum of } 45^{\circ} \text {. The length } \\
\text { of the installation varies, depending on the } \\
\text { specific requirement. There are two different } \\
\text { types of chairlifts available, namely the fixed } \\
\text { grip and the detachable types } \\
\text { (Frankland, 1984). }\end{array}$ & $\begin{array}{l}\text { The main objectives for the installation are to increase working } \\
\text { time at the face area, to eliminate fatigue in travelling to the } \\
\text { workplace, and to increase production by achieving the latter } \\
\text { (Brophy, 1984). From the commissioning of the Phase } 2 \text { shaft } \\
\text { deepening project at BRPM, the decision was to install } \\
\text { dedicated chairlifts opposed to the man riding conveyor belt } \\
\text { installed in the Phase } 1 \text { area. This iinstallations were in } \\
\text { operation since } 2004 \text { and no chairlift related incidents were } \\
\text { recorded thus far. According to safety statistics it was clear } \\
\text { that the chairlift installation is the safer method for the trans- } \\
\text { portation of people in the shaft (BRPM, } 2008 \text { - 2013). The } \\
\text { MHSA contains numerous sections with regards to chairlifts. } \\
\text { The regulations stated here are the minimum requirements } \\
\text { from the DMR. It is the mine's responsibility to have their } \\
\text { own COP and relevant standards to ensure the compliance } \\
\text { as well as safety of all personnel using the chairlifts as a } \\
\text { means of transportation in and out the mine (MHSA, 1996). } \\
\text { This is confirmed through the issuing of a licence to } \\
\text { operate by an Inspector of Machinery from the DMR. }\end{array}$ & $\begin{array}{l}\text { Applicable for further } \\
\text { investigation }\end{array}$ \\
\hline $\begin{array}{l}\text { Chairlift installation } \\
\text { in raisebore shaft }\end{array}$ & $\begin{array}{l}\text { The chairlift system utilizing a raisebore } \\
\text { shaft was investigated as a possible option } \\
\text { or to be used in conjunction with other layout } \\
\text { options (individually as a chairlift leg on its } \\
\text { own or in combination with the rest of the } \\
\text { system). }\end{array}$ & $\begin{array}{l}\text { The minimum angle of inclination is } 2^{\circ} \text {, this is the minimum } \\
\text { angle required to ensure that self-cleaning occurs during the } \\
\text { drilling of the raisebore shaft. The maintenance (preventative } \\
\text { and routine) on the infrastructure is much higher compared to } \\
\text { a normal chairlift installation as a result of the acute angles } \\
\text { it has to operate in. The diameter of raisebore shaft should } \\
\text { be clearly defined and calculated in terms of required } \\
\text { clearance from the sidewalls (including footwall). Special } \\
\text { permission should be granted by the DMR for application of } \\
\text { similar type of arrangement. There should be compliance } \\
\text { with MHSA regarding walking up and down the inclined } \\
\text { shaft when chairlift is standing. This could be during normal } \\
\text { maintenance or during breakdowns (Personal visit, 2008). }\end{array}$ & $\begin{array}{l}\text { Applicable for further } \\
\text { investigation }\end{array}$ \\
\hline $\begin{array}{l}\text { Monorail } \\
\text { transportation } \\
\text { system }\end{array}$ & $\begin{array}{l}\text { Monorails have proven their reliability under } \\
\text { arduous conditions. There is the option } \\
\text { between diesel and electric driven units. } \\
\text { The track bound monorail is easy to control } \\
\text { and safe against derailment compared to a } \\
\text { free-steered vehicle. It has a hoist on board } \\
\text { and one driver can do the loading and } \\
\text { unloading without assistance. The safety } \\
\text { records of monorail systems are phenomenal. } \\
\text { The on-board safety brake system will stop } \\
\text { the train immediately when the system or } \\
\text { human faults lead to an uncontrolled } \\
\text { movement of the train on the rail. Low OPEX } \\
\text { compared to LDV's and UV's (SMT by } \\
\text { Scharf, 2010). }\end{array}$ & $\begin{array}{l}\text { Able to negotiate steep gradients and sharp } \\
\text { horizontal curves and changing gradients. Having a small } \\
\text { cross-sectional area - minimal excavation. Includes its own } \\
\text { load pick-up system. Being able to transport both } \\
\text { personnel and material. Efficient delivery of men (between } \\
60 \text { and } 75 \text { ) and material (up to 15) at } 2 \mathrm{~m} / \mathrm{s} \text {. Diesel } \\
\text { driven (good fuel consumption - no electrical cable or } \\
\text { connection). The mechanical controls and functions } \\
\text { withstand humid and dusty conditions. Small cross- } \\
\text { sectional dimensions ( } 800 \text { mm width) enables the train to } \\
\text { access low and tight roadways and support the mining } \\
\text { operations right at the face. High initial CAPEX (Personal } \\
\text { visit, 2008). }\end{array}$ & $\begin{array}{l}\text { Applicable for further } \\
\text { investigation }\end{array}$ \\
\hline
\end{tabular}




\section{Engineering principles for the design of a personnel transportation system}

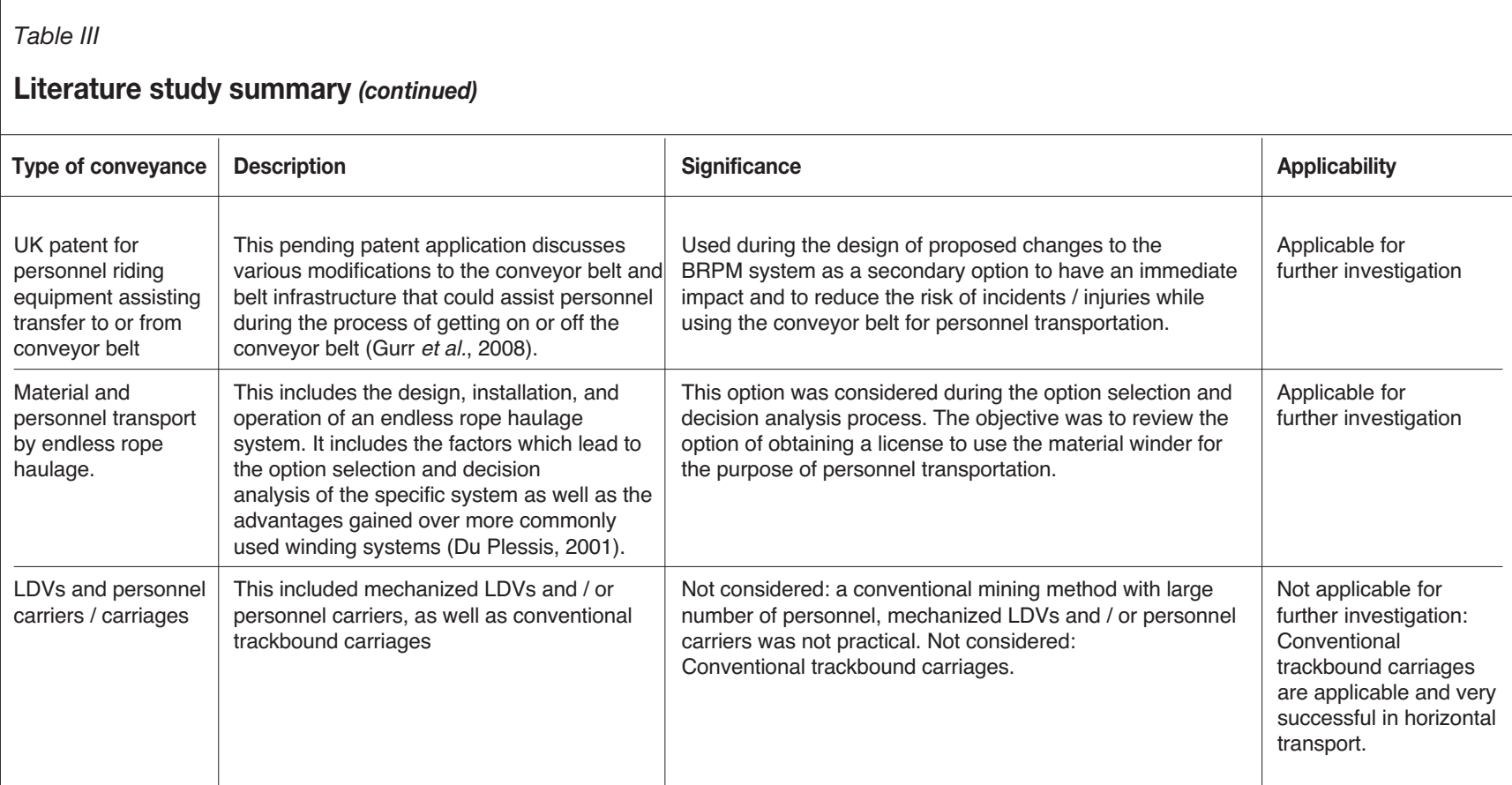

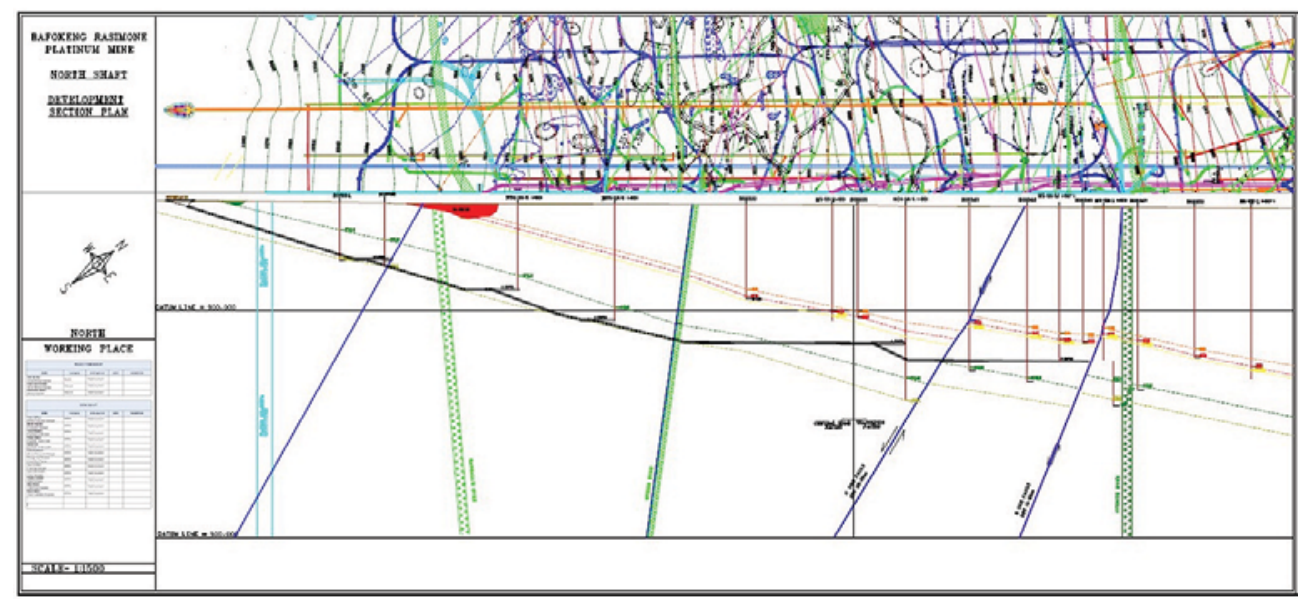

Figure 5-Plan and section view of the North Shaft chairlift decline system design (BRPM, 2013)

worked-out areas. The additional airway as a result of the chairlift decline development will entail major advantages from a ventilation perspective. These include:

$>$ A reduction in the total shaft air resistance, leading to reduced power consumption of the main surface fans

> The additional intake can increase the overall shaft's air intake.

> Lower airflow velocities in the belt decline (less dust generation).

\section{Development and construction schedule}

Owing to the configuration of the chairlift decline and the fact that it will be developed through existing mining infrastructure, it is possible to begin development from six attack points and the schedule has been compiled as such. Figure 5 shows the various attack points from surface and underground from the different operational levels.

CADSMine design and scheduling software was used during the process. Development of the chairlift decline and associated landings and crosscuts has been scheduled at a rate of $32 \mathrm{~m} /$ month (instantaneous). From the scheduling it was concluded that the total duration to complete the development of the chairlift decline was 12 months. A total of $1934 \mathrm{~m}$ of development would be needed.

Construction will be concurrent with the development. Once a leg between two levels has been completed, it will be constructed. The only bottleneck would be the first leg from 


\section{Engineering principles for the design of a personnel transportation system}

surface to level 1, which would take two additional months to complete. Thus, the total development and construction duration would be 14 months.

\section{Estimated CAPEX}

The estimated CAPEX on the mining costs was based on 12 months for development and a total development of $1934 \mathrm{~m}$. It was assumed that development would be conducted by AAP's Capital Development Services (CDS), which is currently developing the Phase 2 declines on both shafts. The development cost used, R3099 per $\mathrm{m}^{3}$, is as per the agreed rate per cubic metre with CDS.

The chairlift costs (infrastructure and installation) were obtained from Sareco, which is installing the Phase 2 chairlifts on both shafts (refer to chairlift requirement summary in Table IV). The total estimated CAPEX for the chairlift decline at North Shaft would be R94 million.

\section{Secondary option (safer platforms for getting on and off the belt)}

\section{Platform modifications}

Having analysed the configuration, particularly of the platforms for getting off the belt, some relatively minor modifications could be made that will greatly assist with the process. The lower conveyor belt is deeply troughed, which together with the fact that the platform itself is elevated above the level of the conveyor belt, means that the rider has to take a step up of approximately $400 \mathrm{~mm}$ to get off the conveyor belt. The platform is also broad, being $1200 \mathrm{~mm}$ from the side of the conveyor belt to the grab rail, and hence the grab rail currently installed is ineffective when getting onto or off the belt.

Getting off the belt while going down the mine is the most challenging action required considering the past safety performance at BRPM. This platform requires the most attention. Figure 6 shows a section of the current configuration of the platform.

One interim solution to improve the safety of the conveyor belt for the purpose of personnel transportation is to change the idlers at platforms going down, replacing troughing idlers with flat idlers for a distance equal to the

\section{Table IV}

\section{Chairlift requirements}

\begin{tabular}{l|c|c|}
\hline & North Shaft & South Shaft \\
\hline $\begin{array}{l}\text { Personnel capacity } \\
\text { Chairlift decline average inclination }\end{array}$ & 900 per hour & 900 per hour \\
\hline Chairlift decline maximum inclination & $17.0^{\circ}$ & $17.9^{\circ}$ \\
\hline $\begin{array}{l}\text { Chairlift decline minimum inclination } \\
\text { (excluding the landing areas, } \\
\text { which are flat) }\end{array}$ & $8.5^{\circ}$ & $19.0^{\circ}$ \\
\hline $\begin{array}{l}\text { Length of decline } \\
\text { Rope speed }\end{array}$ & $1934 \mathrm{~m}$ & $1727 \mathrm{~m}$ \\
\hline $\begin{array}{l}\text { Deceleration limits } \\
\text { (as per SANS 273) }\end{array}$ & $1.5-0.375 \mathrm{~m} / \mathrm{s}^{2}$ & $1.5-0.375 \mathrm{~m} / \mathrm{s}^{2}$ \\
\hline
\end{tabular}

length of the platform plus one idler at either end of the platform. Two transition idlers either side of the platform would be added to assist the belt in changing from troughing idlers to flat idlers and back again

Replacing the troughed idlers with flat idlers will immediately create a flatter transition surface between the belt and the platform and remove the height differential between the two. This is illustrated conceptually in Figure 7 .

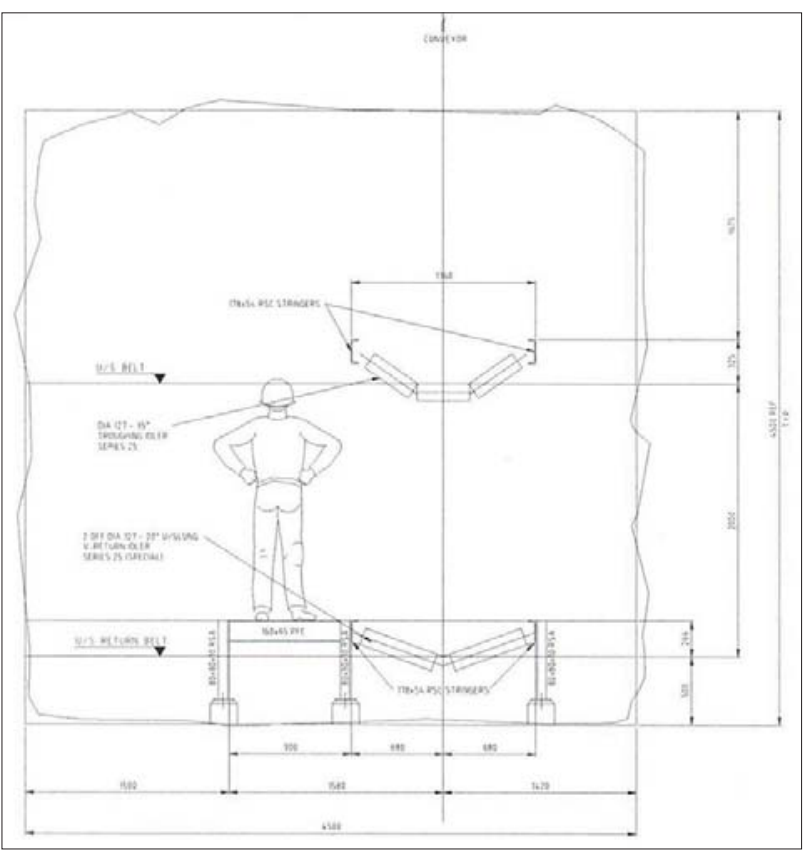

Figure 6-Getting off the belt (going down the mine) - section through platform (bottom belt - existing) (BRPM, 2008)

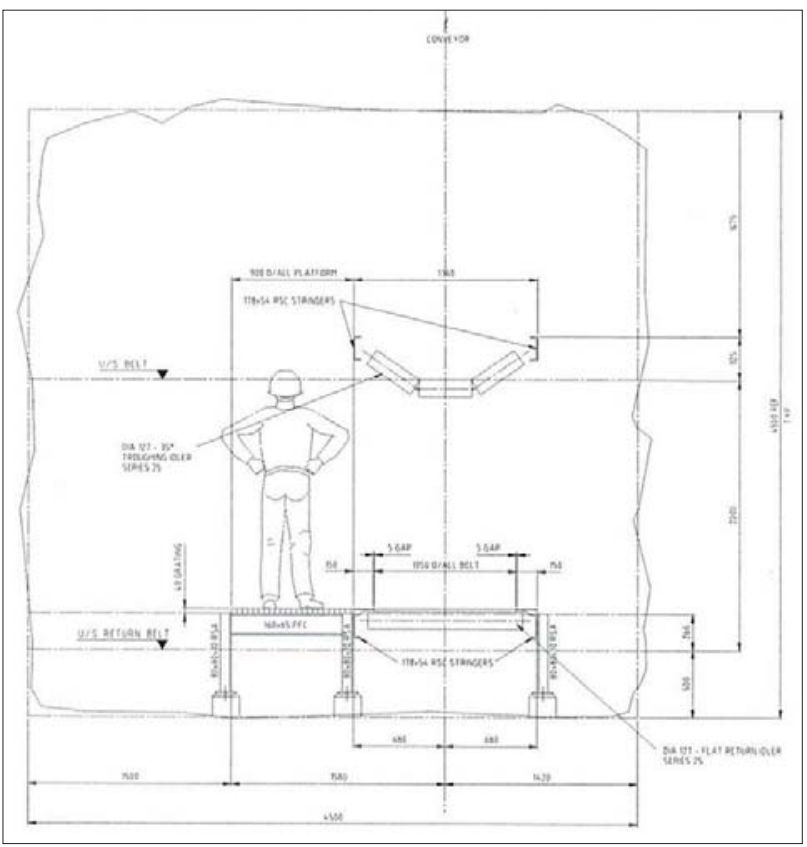

Figure 7-Getting off the belt (going down the mine) - section through platform (bottom belt - modifications) (BRPM, 2008) 


\section{Engineering principles for the design of a personnel transportation system}

Reducing the width of the platform from $1200 \mathrm{~mm}$ to no more than $900 \mathrm{~mm}$ will also allow personnel to utilize the grab rail to steady themselves if in need. As there is no broken rock on the bottom belt there is no reason why this cannot be implemented. It is also recommended that the current grating used for the floor of the platform be replaced by the non-slip variety to prevent people slipping while attempting to brake rapidly.

Although getting off the belt when going out the mine does not carry the same risk as when going down the mine, it would still be of assistance to improve the ergonomics of the platform, particularly when personnel alight off broken rock. This could be done by lowering the platform by approximately $50 \mathrm{~mm}$ to reduce the height differential.

Adjustable trough idlers are proposed for the platform areas used when going up. Flat idlers cannot be used for the ascending conveyor belt as this section of belt carries broken rock and there is a possibility of rock rolling off should flat idlers be incorporated here. Instead, adjustable idlers can be installed, giving the potential for trying various angles of trough to keep broken rock on the belt and provide a flatter belt at platform areas when going out the mine. Adjustable idlers would replace the existing troughing idlers for the length of the platforms. The first option is to install adjustable idlers, which could be tuned to reduce the trough as much as possible without causing spillage from the conveyor belt. The other option is narrowing the platform to $900 \mathrm{~mm}$ so as to allow personnel to utilize the grab rail. These existing platforms as well as the proposed modifications are illustrated in Figure 8 and 9. The estimated CAPEX for the modifications is approximately R1.0 million, as shown in Table $\mathrm{V}$.

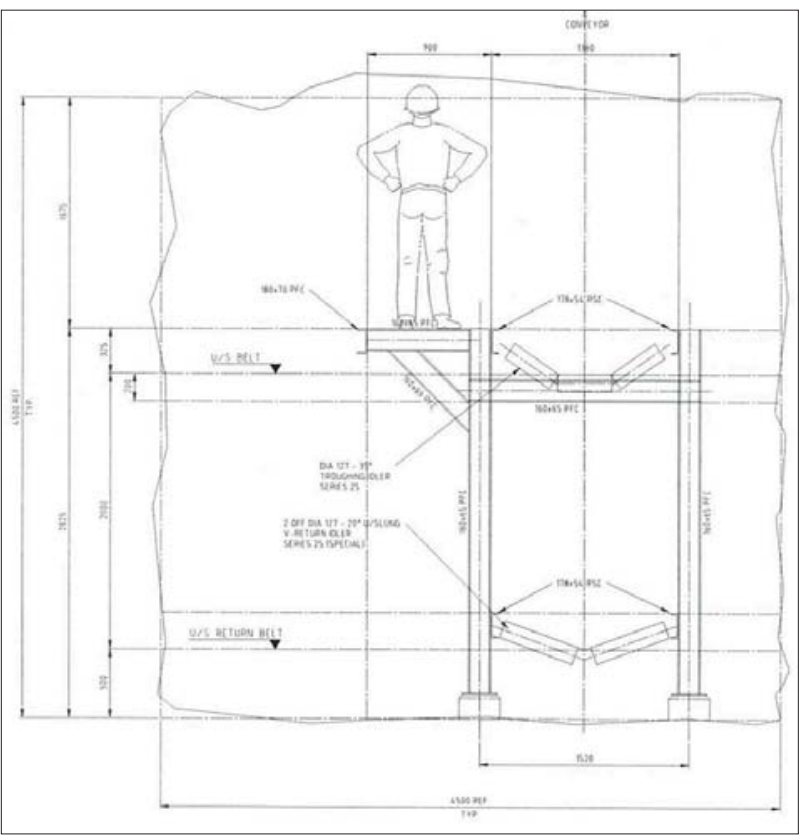

Figure 8-Getting off the belt (going out the mine) - section through platform (top belt - existing) (BRPM, 2008)
Addition of an intermediate conveyor belt for assistance when getting off the belt

Installation of an intermediate conveyor belt for assisting personnel getting off the belt going down the mine is recommended. The speed will be $1.5 \mathrm{~m} / \mathrm{s}$ and the belt can be installed in place of the existing platforms. A $4 \mathrm{~kW}$ variablespeed drive (VSD) and $4 \mathrm{~kW}$ motor driving through a bevel helical gearbox will power the conveyor. A multiply mediumduty conveyor belt has been selected, running on $127 \mathrm{~mm}$ flat idlers and with a skid plate with $324 \mathrm{~mm}$ diameter drive and return pulleys, unlagged. The VSD will allow an optimum speed to be selected should the initial estimate of $1.5 \mathrm{~m} / \mathrm{s}$ not be ideal. A trial-and-error procedure will be run to determine the best speed on the intermediate belt. The estimated CAPEX

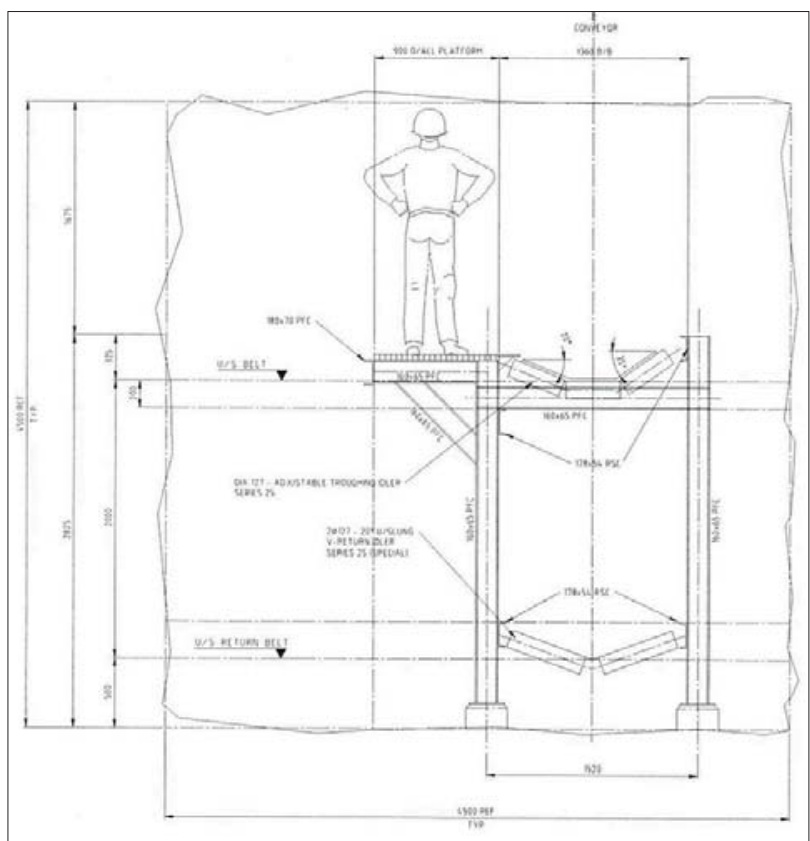

Figure 9-Getting off the belt (going out the mine) - section through platform (top belt - modifications) (BRPM, 2008)

\begin{tabular}{|c|c|c|c|}
\hline \multicolumn{4}{|c|}{ Total estimated CAPEX - North Shaft } \\
\hline Item & Quantity & Price per unit (R) & Total (R) \\
\hline \multicolumn{4}{|c|}{ Primary option } \\
\hline \multicolumn{4}{|c|}{ New chairlift decline } \\
\hline North Shaft total & $1934 \mathrm{~m}$ & 48374 & 93555572 \\
\hline \multicolumn{4}{|c|}{ Secondary options } \\
\hline \multicolumn{4}{|c|}{ Modifications to platform areas } \\
\hline North Shaft total & 5 levels & 205085 & 1025423 \\
\hline \multicolumn{4}{|c|}{ Intermediate conveyor } \\
\hline North Shaft total & 5 levels & 180,368 & 926842 \\
\hline \multicolumn{4}{|c|}{ Endless rope arrangement } \\
\hline North Shaft total & 5 levels & 106022 & 530109 \\
\hline Grand total & & & 96037947 \\
\hline
\end{tabular}




\section{Engineering principles for the design of a personnel transportation system}

for the modifications is approximately R0.9 million, as shown in Table $\mathrm{V}$.

Addition of overhead endless ropeway for assistance when getting off the belt

To assist personnel to get off from the conveyor belt when going down the mine, the installation of an overhead endless rope running across the conveyor belt to the platform is proposed. The system is driven by a $3 \mathrm{~kW}$ VSD with $400 \mathrm{~mm}$ diameter pulleys and a $16 \mathrm{~mm}$ plastic-coated steel rope running at $1.5 \mathrm{~m} / \mathrm{s}$. The idea is for personnel to grab hold of the rope to steady themselves when getting off from the belt to the platform. Since the belt is running at $2.5 \mathrm{~m} / \mathrm{s}$ and the rope at $1.5 \mathrm{~m} / \mathrm{s}$, the effect is that the rope is travelling towards the person. It would be mandatory for all personnel to wear gloves when going down to help prevent possible rope burn. Again, a process of trial and error is required to determine the best speed for the rope and the VSD will allow a suitable speed to be selected. Table $\mathrm{V}$ shows the estimated CAPEX for this installation. Figure 10 illustrates rope assistance at a typical elevation. The estimated CAPEX for the modifications is approximately R0.5 million.

\section{Completed platform modifications}

Figure 11 illustrates a platform complete with all safety enhancements, namely flat idlers, ropeway assistance, and an intermediate belt. These modifications are seen only as a short-term solution to the current problem experienced with personnel transportation at BRPM, and could be done rapidly resulting in an immediate improvement in safety. They will

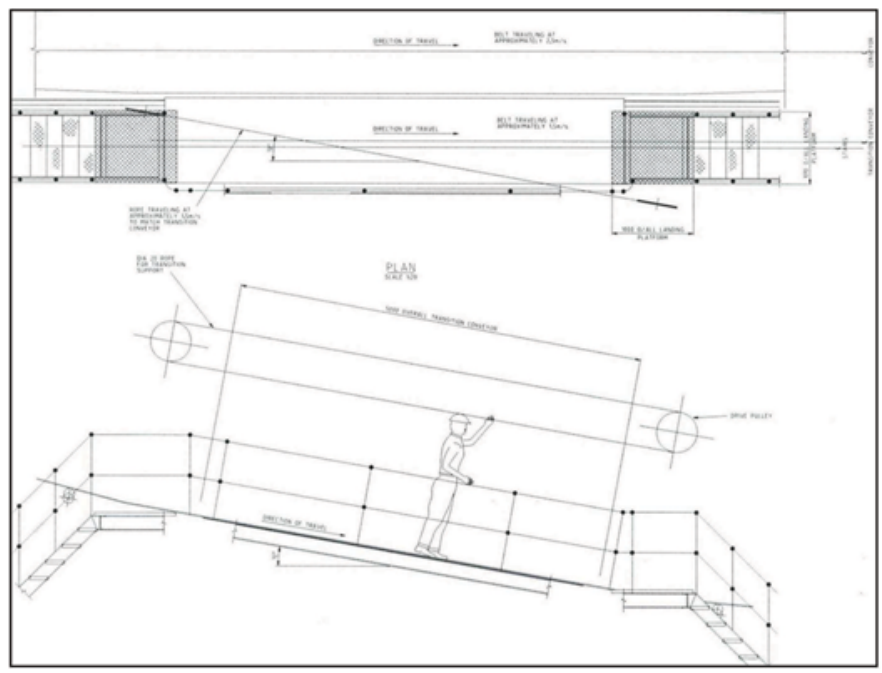

Figure 10 - Rope assistance - typical elevation (BRPM, 2008)

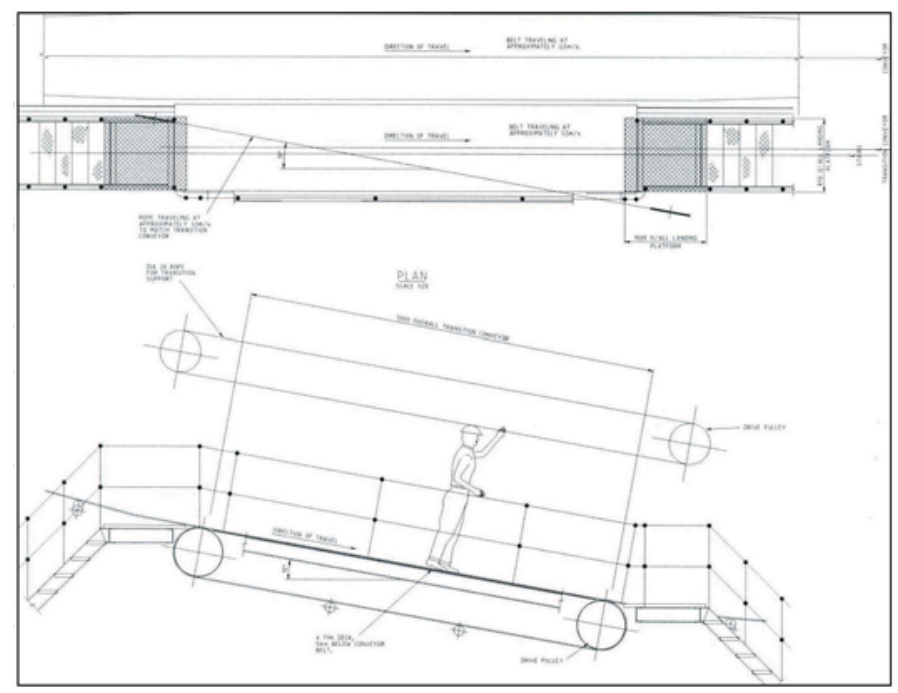

Figure 11-Completely modified platform, including intermediate belt and rope assistance (BRPM, 2008) 


\section{Engineering principles for the design of a personnel transportation system}

also come with a limited CAPEX (Table V) should all modifications prove viable. The reason why emphasis is placed on these modifications is that developing a new decline system at North Shaft and South Shaft would take approximately 12 and 15 months respectively. Two months could be added for installation of the infrastructure.

It is also assumed that approval of the feasibility study for capital funding would take an additional 18 months. Thus it would take approximately 32 and 35 months before the new chairlift declines on North Shaft and South Shaft could be utilized, respectively. In the interim, there would be a continuing risk of injuries/incidents as a result of personnel transportation on the conveyor belt, which could lead to stoppages.

\section{Summary of North Shaft estimated CAPEX}

The total estimated CAPEX for the complete North Shaft installation (primary and secondary options) is approximately $\mathrm{R} 96$ million (Table V). This is based on the assumption that the secondary options would be implemented while the development of the chairlift decline is in progress. This would have an immediate impact on safety. The secondary options could be implemented quickly compared to the 32-month project duration for the chairlift decline.

\section{Analysis and evaluation of results}

In an attempt to reduce injuries on the conveyor belt, VSDs were installed at both shafts at the end of 2008 at a cost of R7.8 million. The intention was to reduce the belt speed to $1.5 \mathrm{~m} / \mathrm{s}$ when personnel are riding. A reduced production of 47\% was simulated by Anglo Technical Division (Jele, 2008). The calculated financial impact at that stage would have been R52.4 million per month if a belt speed of $1.5 \mathrm{~m} / \mathrm{s}$ was maintained.

The decision was taken by mine management to increase the belt speed to $2.0 \mathrm{~m} / \mathrm{s}$ when personnel are travelling on the belt. However, the impact on production persisted, with possible losses of R26.2 million per month. A very tight shaft schedule would have to be implemented to ensure that personnel travel on the belt only when the speed is reduced. VSDs as a stand-alone are not the solution for BRPM. However, in conjunction with the reduction in belt speed, belt training was also reviewed. Sirens were implemented as early warning devices to notify personnel to get off at each level. Cushions were also installed against the rails at each of the landing areas. A soft start and stop mechanism was also installed.

All these initiatives have had a definite impact on safety since their introduction towards the end of 2008 (Figure 2), but accidents/incidents have not been eliminated entirely. Other options will have to be implemented to ensure the belt is running at design capacity, delivering the planned tonnages with no impact on the safety and health of employees.

The primary and secondary options considered would not only reduce the risks of accidents/incidents, but would also allow the mine to utilize the design capacity of the belt 24 hours a day. The total estimated CAPEX for both primary and secondary options at BRPM is approximately R200 million. This amount is relatively small compared to that resulting from possible safety stoppages. It should also be emphasized that these options would play a vital role during the remaining 40 to 50 years of the estimated LOM.

When considering chairlifts as an option compared to conveyor belt riding, some productivity sacrifices were required to ensure the safety of personnel. The simulation conducted by Simulation Engineering Technologies (Nichol, 2009) proved this. Travel time is expected to increase by $33 \%$ as a result of severe queuing, hence personnel would spend less time in the working areas. The only viable option for reducing the impact is to have a pre-determined shaft schedule (per level - beginning of shift and end of shift) to reduce queuing times.

After completion of the study, application for CAPEX was submitted to continue with the primary options (new chairlift decline with infrastructure) at both North and South shafts. The North Shaft CAPEX application was approved and sinking of the chairlift decline at North Shaft is currently in progress.

It is the authors' opinion that with the delay in the new South Shaft chairlift decline, BRPM will continue facing the risk of safety stoppages as a result of accidents/incidents due to conveyor belt riding. The opportunity of utilizing the design capacity of the belt through increased productivity will remain lost.

\section{Additional recommendations}

The mine should start immediately with the secondary options, which will reduce the accident/incident risks while the belt continues to be used for personnel transportation. This will also reduce the risk of safety stoppages, which will minimize unnecessary losses. The total estimated CAPEX for these secondary options was calculated as approximately R5.5 million. These options could be implemented very quickly compared to the 32 and 35 months that would be required for funding approval, development, and construction of the primary options at North Shaft and South Shaft respectively. This will buy the mine some time to complete the formal approval processes. Once the funds are available, the shafts could start immediately with the development of the chairlift declines.

Development of the chairlift declines should start on available MR levels concurrently. The construction of infrastructure and the development of the chairlift declines should take place concurrently. As soon as a leg between two levels is completed, it should be constructed. This will ensure that the project schedule is adhered to.

Once the chairlift decline has been commissioned, the ultimate design speed of the conveyor needs to be determined through adjustment of the installed VSDs. This could have a significant positive spin-off by increasing the tonnage output from the shafts. The belt maintenance schedule needs to be reviewed as unnecessary personnel-detecting safety devices could be removed. This will reduce the maintenance duration and intervals required.

\section{Conclusions}

Despite all the initiatives incorporated to mitigate the risk, BRPM has a very bad safety record with regard to conveyor belt transportation of personnel. 106 injuries were recorded 


\section{Engineering principles for the design of a personnel transportation system}

between 2006 and May 2013. The existing conveyor belts utilized for personnel transportation, installed in the Phase 1 areas of both shafts, were equipped with platforms for getting on and off the belt as well as an array of safety devices, which were designed to ensure the safety of personnel travelling on the belt.

Since the introduction of chairlifts in the Phase 2 areas of both shafts in 2004, BRPM has not recorded a single chairlift accident/incident. The safety statistics clearly show that the chairlift is the safer method for transportation of people into and out of the mine. There is a specific belt training facility on the mine but even with this intensive training programme, accidents/incidents continue to occur. Should there be another belt accident/incident, a safety stoppage could be imposed, which would have a major impact on the mine in terms of production and financial performance. There was therefore the need to identify appropriate option(s) for safe and cost-effective personnel transportation.

The literature study identified several options and combination of options for further investigation during the next phase of the study. These included chairlift installations (in a normal decline or with the variation of utilizing a raisebore shaft for access between levels/connections), a monorail transportation system, modifications to the current belt infrastructure, and utilizing an endless rope haulage system whereby the material winder would be used for material/equipment and personnel transportation.

Further options were identified, including walking, utilizing the current underground conveyor belt system for both broken rock and personnel transportation), LDVs, and personnel carriers, but these were discarded based on the configuration of the decline shafts, BRPM's specific requirements (historical safety performance and mining methods dictating the number of personnel), and compliance with the MHSA.

The options for further investigation were identified followed a process of selection and decision analysis. No option was discarded until proven to be ineffective, unsafe, impractical, and uneconomical. Initially 17 different options were identified during P1. After a process of elimination, the decision was taken to further investigate six options at North Shaft and nine at South Shaft during P2.

Finally, only three options were selected at North Shaft during P3, one of which was a total new chairlift decline with infrastructure and two being modifications to the current conveyor belt infrastructure. Five options were selected at South Shaft during P3, three of which comprised total new declines with infrastructure and two being modifications to the current conveyor belt and belt infrastructure. At the end of P3, only one primary and one secondary option were proven feasible for each of the shafts. Throughout the different stages of the investigation, all relevant responsible departments were involved in the selection and analysis of the various options. The final primary options on both shafts were designed and scheduled using the CADSMine design and scheduling software packages. The proposed design criterion was benchmarked against actual achievements in terms of production, construction, and costs.

Development and construction of the chairlift declines would take 14 months for North Shaft (1934 m development) and 17 months for South Shaft (1727 m development) at a cost pf R3099 per $\mathrm{m}^{3}$ and $\mathrm{R} 3452$ per $\mathrm{m}^{3}$ respectively. The total estimated CAPEX would be approximately R93.6 million for North Shaft and 100.9 million for South Shaft. The secondary options included modifications to the current conveyor belt infrastructure. The total estimated CAPEX for these modifications were calculated as approximately R2.5 million at North Shaft and R3 million at South Shaft.

The total estimated CAPEX to implement both the primary and secondary options at North Shaft and South Shaft was calculated as approximately R96 million and R104 million respectively. The total CAPEX spend of R200 million will have a direct impact in terms of improved safety by eliminating accidents/incidents related to personnel transportation. This is proved by the fact that since the introduction of chairlifts in the Phase 2 areas of both shafts in 2004, BRPM has not recorded a single chairlift-related accident/incident.

It is clear that the chairlift installation is the safer method for personnel transportation at BRPM. The VSDs installed on the current personnel transportation belts are not in themselves a solution. The reduction in conveyor belt speed to $2.0 \mathrm{~m} / \mathrm{s}$ towards end of 2008 definitely improved safety, but the risk of safety stoppages and associated losses remained. Reducing the belt speed to $1.5 \mathrm{~m} / \mathrm{s}$ (refer to Target mine in the literature study), which could have further reduced the number of accidents/incidents, was considered not economical viable for BRPM.

Other options will have to be implemented to ensure that the belt is running at design capacity and safety of personnel is improved. The implementation of chairlifts will result in a $33 \%$ increase in travelling time, since the speed of the chairlift and the spacing of the seats will result in severe queuing. An appropriate shaft schedule will resolve this problem.

To fulfil the objectives and scope of this investigation, it is recommended that both the primary and the secondary options be considered for implementation on North Shaft and South Shaft to reduce or eliminate accidents resulting from belt transportation.

\section{Suggestions for further work}

During the final design and scheduling of the chairlift declines, the following aspects should be considered and incorporated:

> An appropriate portal design in the weathered zone

> The sizes of excavations should be minimized and important excavations should not be sited in areas where geological features exist

- Excavations should be placed so as to avoid sterilization of the UG2 reserves

> Development rates should be slower through known features such as the weathered zone, shear zone, and UG2 fault. A robust support design as per rock engineering recommendations will also be required when mining through these features and when intersecting sills.

Consideration of the above would require re-evaluation of the project duration and the CAPEX required. 


\section{Engineering principles for the design of a personnel transportation system}

The future planning for North Shaft indicates that the shaft will be developed to level 13, with production from the UG2 stopes in the upper levels of the mine taking place concurrently with MR stoping in the lower levels. Although the total output from the shaft will remain constant, the geographic spread of the operations is likely to put additional strain on the materials handling system. For this reason it is suggested that developing a decline of sufficient width $(6 \mathrm{~m})$ to accommodate both a chairlift and a winder system for materials transport be investigated. This would have the effect of almost doubling the CAPEX of the decline and raise several safety issues with regard to transporting men and material in the same excavation. A detailed simulation of the logistics should be carried out in order to ascertain the risk to production before a decision is taken in this regard.

The installation of the secondary options/modifications to the current belt infrastructure may require additional OPEX with regard to increased electricity consumption, additional engineering requirements (maintenance and breakdowns), and labour, and this should be investigated.

The additional OPEX requirements as a result of the chairlift installations on both shafts will have to be considered. This will include the following:

> Normal running of the chairlift and costs associated with increased electricity consumption and maintenance (preventative maintenance and breakdowns)

> Labour requirements in terms of chairlift attendants and engineering personnel responsible for maintenance. Training requirements should also be considered.

The trade-off between the abovementioned factors and the possible savings once the chairlifts are commissioned should be determined. Once the conveyor belt is utilized only for broken rock transportation, huge savings could result due to reduced maintenance, with specific reference to safety devices, as well as a possible reduction in labour requirements (belt attendants and engineering personnel).

The increase in available belt time as well as the increase in conveyor belt speed will have to be determined. These will lead to an increase in belt capacity and overall potential increase in tonnage output from the shafts. The business planning process will have to be revisited to utilize this potential. This could have a definite financial benefit for BRPM and its stakeholders.

\section{Acknowledgements}

> To BRPM and AAP, Rustenburg (RSA) for permission to publish this article.

> To colleagues at BRPM and AAP, Rustenburg for their contributions to and assistance towards submitting this article.

\section{References}

Anglo Gold Ashanti Kopanong Mine. 2008. Personal communication, 14 April.

Anglo American Platinum Union Section Mine. 2008. Personal communication, 18 August.
BRoPHy, G J. 1984. Chairlift Installations at No. 1 Shaft Western Holdings Holdings Division. Proceedings of the Underground Transport Symposium, 1986 Edgar, R.C.R. (ed.). Special Publication no. 1. South African Institute of Mining and Metallurgy, Johannesburg. pp. 167-185.

BRPM. 2007-2013. Personal communication.

BRPM SAFETy DEPARTMENT, 2013. Personal communication, 27 August.

Du PLESSIS, G.L. 2001. Material and personnel transport by endless rope haulage - the 21st century approach. Proceedings of the 6th International Symposium on Mine Mechanisation and Automation, Sandton Convention Centre, South Africa, 25-28 September, 2001. Willis, R.P.H. (ed.). South African Institute of Mining and Metallurgy, Johannesburg.

FRANKLAND, J.R. 1984. Chairlifts for the South African mining industry. Underground Transport Symposium, 1986. Edgar, R.C.R. (ed.) South African Institute of Mining and Metallurgy, Johannesburg. pp. 153-166.

GuRR, M.E. and JENkins, P. 2008. Man-riding conveyor equipment assisting transfer to or from conveyor. British Patent 2059376A.

Harmony Gold Mining Co Ltd v National Union of Mineworkers (NUM) and OTHERS (J367/12). 2012. ZALCJHB 32; (2012) 33 ILJ 2609 (LC) (14 March 2012), Johannesburg Labour Court, Johannesburg, South Africa.. http://www. SAFLII/Databases/South Africa: Johannesburg Labour Court, Johannesburg/2012/[2012] ZALCJHB 32 [Accessed 23 August 2013].

JELE, Z. 2008. Anglo Platinum Bafokeng Rasimone Platinum Mine Conveyor Simulation Report. March 2008.

South AfricA. 1996. Mine Health and Safety Act, Act 29 of 1996. http://www.acts.co.za/mine-health-and-safety-act-1996/index.html

NichoL, S. 2009. Anglo Platinum Bafokeng Rasimone platinum mine personnel transportation simulation report (Third draft, 5 October 2009).

SCHARF. 2010. Solutions for Mining Transport (SMT). http://www.smtscharf.com [Accessed 20 August 2010] .

TARGET Gold Mine. 2013. Mining Technology, 2013. http://www.miningtechnology.com/projects/target/ [Accessed 23 August 2013].

VAn HEERden, G.M.J. 2008. BRPM chairlift investigation presentation. Anglo American Platinum, Johannesburg.

Van HeERden, G.M.J. 2008. BRPM 2009 Budget presentation. Anglo American Platinum, Johannesburg.

VAn HeERden, G.M.J. 2008. BRPM MES 2009 presentation. Anglo American Platinum, Johannesburg.

VAn HeErden, G.M.J. 2014. Engineering principles for the design of a new / existing mine's personnel transportation system. MEng thesis, University of Pretoria. 